\title{
Tourism Suitability, and Carrying Capacity : Prospect Ecotourism (Case Study in Marina Beach Semarang)
}

\author{
Alin Fithor, S. Budi Prayitno., Frida Purwanti, Agus Indarjo \\ Coastal Resources Management, Faculty of Fisheries and Marine Science, Diponegoro University, \\ 50275 Tembalang, Semarang
}

\begin{abstract}
Marina beach in the city of Semarang is one of the interesting marine attractions, interesting because it is only one of the tourist destinations in the middle of the city. This results in tourists only knowing the tourist recreation. This study aims to combine current conditions where collaboration between Tourism suitability and Carrying capacity of the region as an evaluation and certainly become a prospect towards the future of marine tourism. The results show that the location of the marina beach is not appropriate (TS) with a value of 1.82 in terms of land suitability for the beach recreation category and the carrying capacity of the area for beach recreation is still likely to be improved, but for sports tourism and fishing tourism has been saturated or dense. New innovations are needed in making beach tourism locations for the latest marine tourism recreation in locations in the city of Semarang and are really still naturally accompanied by sound strategies and policies
\end{abstract}

Keywords : Tourism suitability / Carrying capacity / Ecotourism / Marina beach

\section{Introduction}

Marina Beach is a beach that is managed by the Central Java Provincial Government and is a beach located in Semarang City and included in the Region III City Region (BWK III) of West Semarang District. In Semarang City's Regional Spatial Plan (RTRW), it is stated that BWK III has one function as a marine tourism [19].

Even so, it is very natural that in the Marina Beach area stands housing, trade, industry, factories, schools and play areas. As the main location of tourism, especially marine tourism, this beach is one of the beaches that is very popular with the people of Semarang and surrounding areas for beach recreation, sports tourism and fishing tours available so that it has an average number of visitors reaching 400 people per day [23].

* Corresponding author : $\underline{\text { alinfithor@students.undip.ac.id }}$ 
The marine tourism sector is built aimed at being able to increase economic growth, overcome boredom, improve people's welfare, eradicate poverty, alternative building tourism and overcome unemployment. Basically, marine tourism development is inseparable from the role of the community and local government as a regulator. This role can be implemented in various forms of marine tourism service business [2].

This tourism object has the potential to be developed, because most of the natural attractions offer natural beauty that is still natural and interesting. In fact the existence of the potential of these natural tourism objects has not been able to develop optimally $[19,23]$.

The younger age group has relatively more free time and also has a tendency to use their free time to travel to natural attractions, namely marine tourism [2].

The city of Semarang is a coastal city on the north coast of Java, with 60 percent of Indonesia's population residing on the island of Java, which is directly affected by the ocean. This condition has become a valuable component, including ecosystems, communities and socioeconomic risks under pressure from marine dynamics on climate change that is classified as vulnerable. Vulnerability is the magnitude of the function of change and the impacts and variations of climate change, [21].

The cause of sea level rise as an indicator of climate change in the coastal area of Semarang city which reached $0.8 \mathrm{~mm}$ / year and the average land subsidence ranged between 6-19 cm / year, causing coastal communities and marine tourism areas, when their social economy depends on resources, it becomes increasingly difficult to obtain. Land subsidence has been reported to affect vulnerability. The study of the effects of rising sea levels is very important to affect coastal cities. Climate change through rising sea levels has a tendency for coastal areas to be inundated, as a result the balance of coastal areas, especially marine tourism will be disrupted [13,17,21].

However, there are good things that have been studied previously, namely the lowest level of coastal vulnerability is in Maron Beach, Marina Beach and Tanah Mas with a value of 2.8. $\mathrm{X} 3$, then with that it also becomes an advantage that the potential for coastal hazards with the lowest value is in the villages of Randugarut, Karanganyar, Tugurejo, Marina Beach and Tanah Mas with a value of 1.25 [21].

Based on the analysis and calculation, it was found that the coastline decreased $0.49 \mathrm{~km}$ from 2005 to 2010 , and tilted $3.30 \mathrm{~km}$ from 2010 to 2017 . The abrasion that occurred was 285.07 ha and an increase of 2.40 ha. [13], It is important to know the perceptions and participation of local communities to facilitate in designing control strategies and new policies that can be accepted by the local community [7].

\section{Material and Methods}

This research was conducted in the coastal area of the city of Semarang precisely located on the marina beach, the legendary beach in the city of Semarang. [1-2, 23]. this location at Figure 1.

The marina beach is better managed among several other beaches, with good management can produce some number of visitors who can increase the marine tourism area, besides nonnatural tourism in the city of Semarang. [2,23]

This is an evaluation for the authors to the future as a prospect of better utilization and management, especially in the management of the area. As well as the provision of other coastal areas that are considered necessary and maximum especially for educational tourism. $[8,20]$ 


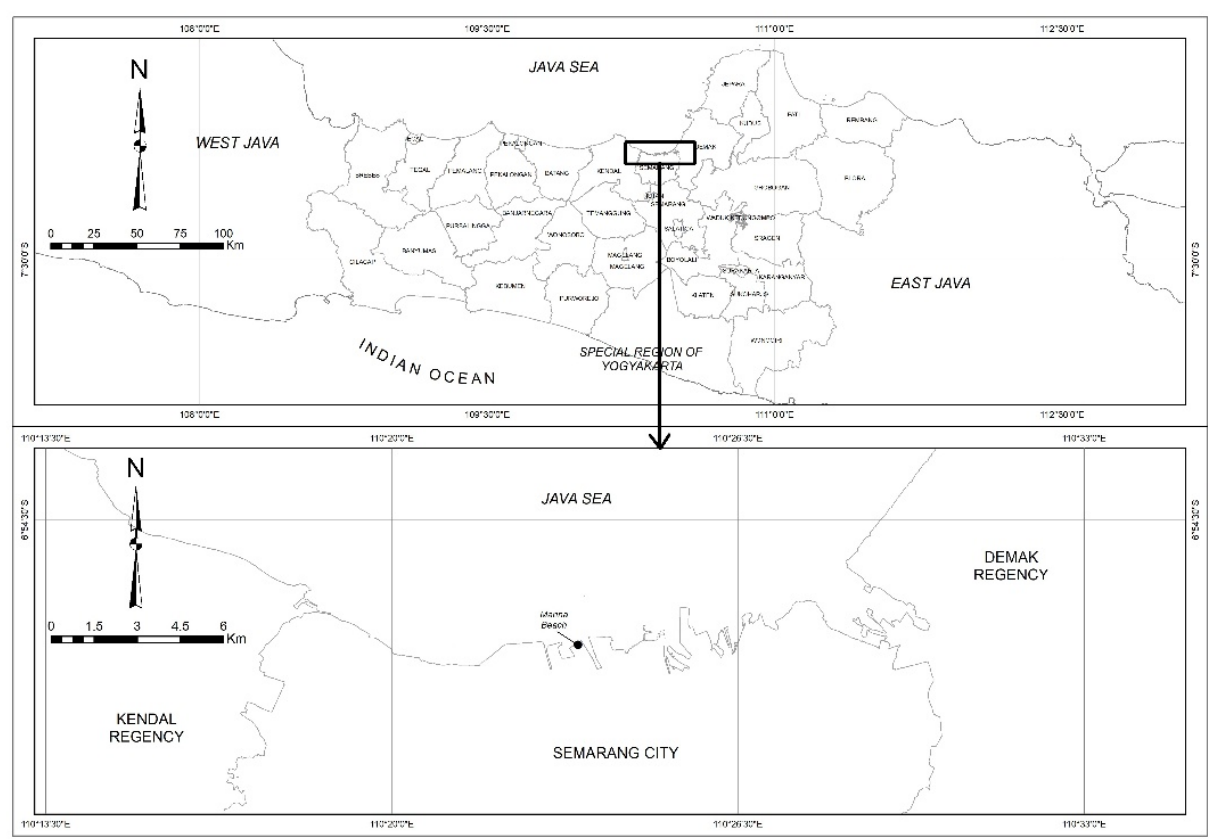

Fig 1. Location Research

\subsection{Method of Collecting Data}

Data collected includes averages and characteristics of tourist destination areas including: tourism suitability of coastal land with 4 sample point locations and carrying capacity of the region in the form of: beach recreation categories, sports tourism and fishing tourism [8] and with supported from several reliable data sources $[8,20]$. then in a qualitative description described in the form of evaluation and future prospects.

\subsection{Method of Data Analysis}

The data begins by describing the number of visitors and the amount of updated income from the results of the relevant tourism institution [19] then compiled with a tabulation system and analyzed using the matrix scoring method for : land suitability of the coastal recreation category and carrying capacity of the area. 


\subsubsection{Tourism Suitability of The Coastal Recreation Category Analysis}

In this case, will approximately by land suitability of the coastal recreation category beside Table 1.

Table 1. Tourism Suitability of The Coastal Recreation Category Analysis

\begin{tabular}{|c|c|c|c|}
\hline Parametre & Value & Category & Score \\
\hline \multirow[t]{4}{*}{ Type of Beach } & 0.200 & White sand & 3 \\
\hline & & $\begin{array}{l}\text { White sand mixed with coral } \\
\text { fragments }\end{array}$ & 2 \\
\hline & & Black sand, a little steep & 1 \\
\hline & & Mud, Rocky, Steep & 0 \\
\hline \multirow[t]{4}{*}{ Beach Width (m) } & 0.200 & $>15$ & 3 \\
\hline & & $10-15$ & 2 \\
\hline & & $<10$ & 1 \\
\hline & & $<3$ & 0 \\
\hline \multirow[t]{4}{*}{ Sand Base Material } & 0.170 & Sand & 3 \\
\hline & & Sandy coral & 2 \\
\hline & & Muddy sand & 1 \\
\hline & & Mud, sandy mud & 0 \\
\hline \multirow[t]{4}{*}{ Water Detph (m) } & 0.125 & $0-3$ & 3 \\
\hline & & $>3-6$ & 2 \\
\hline & & $>6-10$ & 1 \\
\hline & & $>10$ & 0 \\
\hline \multirow[t]{4}{*}{ Water Brightness (\%) } & 0.125 & $>80$ & 3 \\
\hline & & $>50-80$ & 2 \\
\hline & & $20-50$ & 1 \\
\hline & & $<20$ & 0 \\
\hline \multirow{4}{*}{$\begin{array}{l}\text { Current } \\
\text { Velocity(cm/detik) }\end{array}$} & 0.080 & $0-17$ & 3 \\
\hline & & $17-34$ & 2 \\
\hline & & $34-51$ & 1 \\
\hline & & $>51$ & 0 \\
\hline \multirow[t]{4}{*}{ Beach Slope (o) } & 0.080 & $<10$ & 3 \\
\hline & & $10-25$ & 2 \\
\hline & & $>25-45$ & 1 \\
\hline & & $>45$ & 0 \\
\hline \multirow[t]{4}{*}{ Coastal Land Cover } & 0.010 & Coconut tree, open land shrubs & 3 \\
\hline & & $\begin{array}{l}\text { Shrubs, scrub, low grass, } \\
\text { savanna }\end{array}$ & 2 \\
\hline & & High scrub & 1 \\
\hline & & $\begin{array}{l}\text { Mangrove forest, settlement, } \\
\text { harbour }\end{array}$ & 0 \\
\hline Hazardous Organisms & 0.005 & Nothing & 3 \\
\hline
\end{tabular}




\begin{tabular}{|c|c|c|c|}
\hline \multirow{7}{*}{$\begin{array}{l}\text { Availability of fresh } \\
\text { water }(\mathrm{km}) .\end{array}$} & \multirow{7}{*}{0.005} & Sea urchins & 2 \\
\hline & & Sea urchins, stingrays & 1 \\
\hline & & Sea urchins, stingrays, shark & 0 \\
\hline & & $<0.5$ & 3 \\
\hline & & $>0.5-1$ & 2 \\
\hline & & $1-2$ & 1 \\
\hline & & $>2$ & 0 \\
\hline
\end{tabular}

Source: Direct observation [8]

Information :

$$
\begin{aligned}
\text { Amount } & =(\text { Score } x \text { Quality }) \\
& =\text { Very suitable with the IKW value }>2.5 \\
& =\text { In accordance with the value of } 2.0<\mathrm{IKW}<2.5 \\
& =\text { Not suitable with value } 1<\mathrm{IKW}<2.0 \\
& =\text { Very inappropriate }<1
\end{aligned}
$$

Quality $=$ The importance of a parameter to the suitability of the region

Score $=$ Value of research results

Class compatibility index of mangrove and beach tourism are: S1: Very suitable, with a value of $83-100 \%$; S2: Suitable, with a value of $67-<83 \%$; S3: In accordance with the requirements, with a value of 50 -

$<67 \%$; N: Not suitable, with a value $<50 \%$. [8]

\subsubsection{Regional Carrying Capacity Analysis}

Estimating the carrying capacity of marine tourism activities referring to marine tourism should not exceed $10 \%$ of the total utilization zone. The carrying capacity equation used is as follows [8]:

Table 2. Carrying Capacity

\begin{tabular}{lllccc}
\hline No & Category & $\mathrm{K}$ & $\mathrm{Lp}(\mathrm{Lt})(\mathrm{m} 2)$ & $(\mathrm{Wp})$ (hour) & $(\mathrm{Wt})$ (hour) \\
\hline 1. & Recreation only & 1 & 25 & 3 & 6 \\
2. & Sport recreation & 1 & 25 & 3 & 6 \\
1 & Fishing recreation & 1 & 25 & 2 & 8 \\
3. & Fis & & & \\
1 & & & & & \\
\hline
\end{tabular}

Source : Direct observation [8]

Assess the carrying capacity of the area to be able to accommodate the number of visitors. Calculation of the carrying capacity of the region in the form of a formula as follows:

$$
\mathrm{CC}=\mathrm{K} X \underset{\mathrm{Lt}}{\mathrm{Lp}} \underset{\mathrm{Wp}}{\mathrm{Wt}}
$$

Information :

$\mathrm{CC}=$ Carrying capacity of tourist areas $=$ people $/$ day

$\mathrm{K}=$ Ecological potential of visitors per unit area unit 
$\mathrm{Lp}=$ Area or length of area that can be utilized

$\mathrm{Lt}=$ Unit area for certain categories

$\mathrm{Wt}=$ Time provided by the region for tourism activities in one day

$\mathrm{Wp}=$ Time spent by visitors for each particular activity

\section{Result and Discussion}

\subsection{Tourism Suitability for Beach Recreation}

The presence of white sand is an attraction compared to the marina beach, but the forced situation makes visitors become potluck attracting tourists to visit the island in the peak season. [5] and of course strategic identification is the key to good management [4]. [19] Surely it will affect the survival of the surrounding residents, [22-23] at this time it has not focused on satellite imagery for managing the carrying capacity of the region, it will also be planned later with the support of satellite imagery. [1,5] Interviews especially with city leaders will certainly be an evaluation for this marina beach whether it is still in accordance with the land or not. 12] land suitability is certainly in collaboration with residents around the coast of the marina by placing a choice of objects for migration to the upper part of Semarang city, [5-7] policies already exist from the previous year but need to be evaluated and improved in accordance with existing land suitability, [26] analysis of tourist visits is needed as a tool for management without building a new location, [12.7-8] the economic value is uncertain but the relationship between the government and the government should raise the topic of economic value other than income, waste certainly becomes an absolute tourism undertaking with parties Third [14], managers focus on location security and convenience. In this result, $1,790+1,790+1,915+1,790=1.825$ (not suitable value) of marina beach.

Table 4. Tourism Suitability of The Coastal Recreation Category Analysis Result

\begin{tabular}{|c|c|c|c|c|c|}
\hline Parametre & Value & $\begin{array}{c}\text { Station } \\
1 \\
\end{array}$ & $\begin{array}{c}\text { Station } \\
2 \\
\end{array}$ & $\begin{array}{c}\text { Station } \\
\mathbf{3} \\
\end{array}$ & $\begin{array}{c}\text { Station } \\
4 \\
\end{array}$ \\
\hline Type of Beach & 0.200 & 0 & 0 & 0 & 0 \\
\hline Beach Width (m) & 0.200 & 0.600 & 0.600 & 0.600 & 0.600 \\
\hline $\begin{array}{l}\text { Sand Base } \\
\text { Material }\end{array}$ & 0.170 & 0.340 & 0.340 & 0.340 & 0.340 \\
\hline Water Detph (m) & 0.125 & 0.375 & 0.250 & 0.375 & 0.250 \\
\hline $\begin{array}{l}\text { Water Brightness } \\
(\%)\end{array}$ & 0.125 & 0.125 & 0.250 & 0.250 & 0.250 \\
\hline $\begin{array}{l}\text { Current } \\
\text { Velocity }(\mathrm{cm} / \text { detik})\end{array}$ & 0.080 & 0.160 & 0.160 & 0.160 & 0.160 \\
\hline Beach Slope (o) & 0.080 & 0.160 & 0.160 & 0.160 & 0.160 \\
\hline $\begin{array}{l}\text { Coastal Land } \\
\text { Cover }\end{array}$ & 0.010 & 0 & 0 & 0 & 0 \\
\hline $\begin{array}{l}\text { Hazardous } \\
\text { Organisms }\end{array}$ & 0.005 & 0.015 & 0.015 & 0.015 & 0.015 \\
\hline $\begin{array}{l}\text { Availability of } \\
\text { fresh water }(\mathrm{km}) \text {. }\end{array}$ & 0.005 & 0.015 & 0.015 & 0.015 & 0.015 \\
\hline Total & 1,000 & 1,790 & 1,790 & 1,915 & 1,790 \\
\hline
\end{tabular}

Source : [8], Field observation 


\subsection{Carrying Capacity}

Maintaining coastal productivity is certainly a goal for fisheries productivity around the coastal location [4-5], plus the procurement of a number of mangrove forests of at least 1 or 2 trees with more natural abilities to be able to increase the carrying capacity of the area, [3] better and planned management models for returned to the city government as a reason to stabilize the carrying capacity, at this time it has not been focused on satellite imagery for managing the carrying capacity of the region, it will also be planned later with the support of satellite imagery [22]. Calculating mathematically is certainly a consideration in fundamental management [13], coupled with coastal vulnerability analysis [21]. Changing the paradigm or framework of thinking that the location of the beach again and again is not only on the marina beach, and not just the old city. So that the carrying capacity is more evenly distributed to other beach locations. In this case, much recreation only has a LOW carrying capacity then Fishing and Sport recreation.

Table 5. Regional Carrying Capacity Result

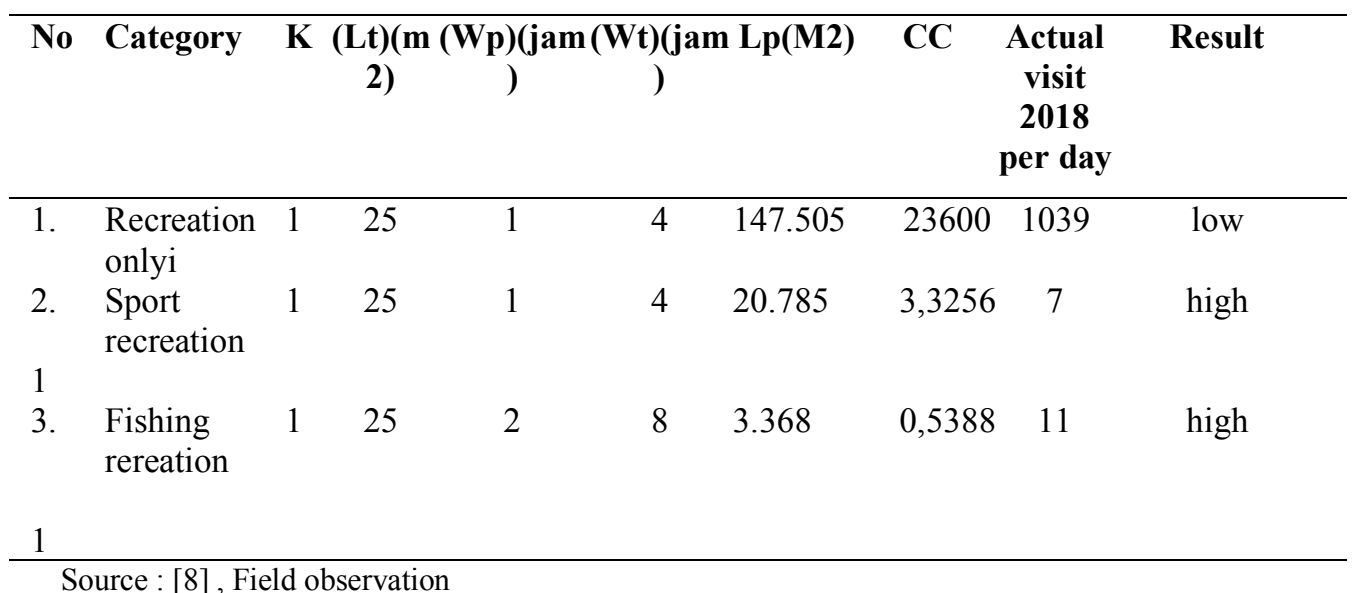

The concept of carrying capacity of a region provides useful strategies for achieving objectives that can be applied in a management context [21]. Therefore, of course crosssectoral cooperation is needed with one of the manifestations is to transfer the management of this coastal marine tourism area to be owned by the Semarang city government and also added with other beaches. 


\section{Conclusion}

Based on the above conclusions, it is necessary to underline that the current marina beach conditions have increased visitor levels, with water conditions that are not in accordance with the beach recreation category for marine tourism, it is necessary to prepare other forms of tourism locations that can form the basis of government policy both the provincial government Central Java and Semarang City Government. So that the carrying capacity of the region can be evaluated as a material policy consideration.

\section{Acknowledgement}

This research received no specific grant from any funding agency in the public, commercial, or not-for profit sectors.

\section{References}

1. A. Fithor, J. Sutrisno, A.indarjo. Mangrove Ecosystem Management Strategy in Maron Beach Semarang. Ilmu Kelautan : Indonesian Journal of Marine Science. Universitas Diponegoro. Semarang. 23(4) (2019)

2. A. Listyowati, E.K.S.H. Muntasib, R. Hermawan. Permintaan Wisata Alam di Kota Semarang bagi Kelompok Usia Muda(Nature-Based Tourism Demand at Semarang City for Young Age Group). Media Konservasi 18, No. 2 Agustus 2013 : $101-106$. Institut Pertanian Bogor (2016)

3. Artiningsih, J. S. Setyono, R. K. Yuniartanti. The Challenges of Disaster Governance in an Indonesian Multihazards City: A Case of Semarang, Central Java. ProcediaSocial and Behavioral Sciences, 226, 347-353 (2016)

4. Aspiany, S. Anggoro, F. Purwanti, B. I. Gunawan. Evaluating Ecotourism Development in Bontang: Water Quality, Compatibility, and Carrying Capacity The 2nd International Symposium on Marine Science and Fisheries (ISMF2) - 2019. IOP Conf. Series: Earth and Environmental Science 370 (2019) 012049. IOP Publishing (2019)

5. Aspiany, S. Anggoro, F. Purwanti, B. I. Gunawan. Strategies for sustainable ecotourism development in the marine waters of Bontang City, Indonesia. AACL Bioflux, 2019, 12, Issue 5. http://www.bioflux.com.ro/aacl (2019)

6. D. Lithgow, M. L. Martínez, J. B. Gallego-Fernández, R. Silva, D. L. RamírezVargas. Exploring the Co-occurrence between Coastal Squeeze and Coastal Tourism in a Changing Climate and its Consequences, Tourism Management, 74, 43-54 (2019)

7. F. D. Pratiwi, M. Zainuri, P. W. Purnomo, F. Purwanti. Stakeholder perception and participation in relation to success rate of water hyacinth control program in the Rawa Pening Lake. AACL Bioflux, 11, Issue 4. http://www.bioflux.com.ro/aac (2018)

8. F. Yulianda. Ekowisata Perairan : Suatu Konep Kesesuaian dan Daya Dukung Wisata Bahari dan Wisata Air Tawar. IPB Press, Bogor. 92 hlm. (2019)

9. G. Liu, F. Cai,, H. Qi, J. Zhu, G. Lei, H. Cao, J. Zheng. A Method to Nourished Beach Stability Assessment: The Case of China, Ocean and Coastal Management, 177, 166178 (2019)

10. H. Yanfika, K. K. Rangga, B. Viantimala, I. Listiana, A. Mutolib, A. Rahmat. Evaluation of the Success of Programs and Strategy for Sustainable Coastal Community Development in Tanggamus Regency. Young Scholar Symposium on 
Science Education and Environment 2019 IOP Conf. Series: Journal of Physics: Conf. Series, 1467 (2020) 012026 IOP Publishing (2019)

11. I. Buchori, A. Pramitasari, A. Sugiri, M. Maryono, Y. Basuki, A. W. Sejati. Adaptation to Coastal Flooding and Inundation: Mitigations and Migration Pattern in Semarang City, Indonesia, Ocean and Coastal Management, 163, 445-455 (2019)

12. I. Rodella, F. Madau, M. Mazzanti, C. Corbau, D. Carboni, K. Utizi, U. Simeoni. Willingness to Pay for Management and Preservation of Natural, Semi-urban and Urban Beaches in Italy, Ocean and Coastal Management, 172, 93-104 (2019)

13. Irsadi, S. Anggoro, T. R. Soeprobowati, M. Helmi, A. S. E. Khair. Shoreline and Mangrove Analysis along Semarang-Demak, Indonesia for Sustainable Environmental Management. JPII. 8 (1) (2019) 1-11 Jurnal Pendidikan IPA Indonesia. Universitas Negeri Semarang (2019)

14. J. H. Brand, K. L. Spencer. Potential Contamination of The Coastal Zone by Eroding Historic Landfills, Marine Pollution Buletin, 146, 282-291 (2019)

15. J. S. A. do Carmo. The Changing Paradigm of Coastal Management: The Portuguese Cse, Science of the Total Environment, 695, 133807, 1-13 (2019)

16. K. L. Leoa, C. L. Gillies, J. A. Fitzsimons, L. Z. Halee, M. W. Beckf. Coastal Habitat Squeeze: A Review of Adaptation Solutions for Saltmarsh, Mangrove and Beach Habitats. Ocean and Coastal Management, 15, 180-190 (2019)

17. L. Nurhidayah, A. McIlgorm, Coastal Adaptation Laws and The Social Justice of Policies to Address Sea Level Rise: An Indonesian Insight, Ocean and Coastal Management, 171, 11-19 (2019)

18. Lisa-Michéle Bott, B. Braun. How do Households Respond to Coastal Hazards? A Framework for Accommodating Strategies using The Example of Semarang Bay, Indonesia, International Journal of Disaster Risk Reduction, 37, 101177, 1-9 (2019)

19. M. F. Zaki, A. Pujiati. Analisis Kebijakan Pengembangan Wisata Bahari Pantai Marina Tahun 2010-2015. EFFICIENT : Indonesian Journal of Development Economics https://doi.org/10.15294/efficient.v1i3.27876 1 (3) (2018)

20. Sugiyono. Metode Penelitian Kuantitatif, Kualitatif, Research and Development. Bandung : Penerbit Alfabeta (2017)

21. Sunaryo, Ambariyanto, D. N. Sugianto, M. Helmi, A. H. Kaimuddin, A. Indarjo. 2017. Risk Analysis of Coastal Disaster of Semarang City, Indonesia. E3S Web of Conferences. 31, 12009 (2018). ICENIS 2017

22. W. Zheng, F. Cai, S. Chen, J. Zhu, H. Qi, H. Cao, S. Zhao. Beach Management Strategy for Small Islands: Case Studies of China, Ocean and Coastal Management, 104, 9-17 (2019)

23. Y. Mardiyani, Murwatiningsih. Pengaruh Fasilitas dan Promosi Terhadap Kepuasan Pengunjung melalui Keputusan Berkunjung Sebagai Variabel Intervening pada Objek Wisata Kota Semarang. Management Analysis Journal 4 (1). Universitas Negeri Semarang. (2015) 